\title{
İmmün Kontrol Noktası İnhibitörleri Ctla-4 ve Pd-1/Pd-I1'in İmmünoterapideki Yeri
}

\author{
Kübra KAHVECi ${ }^{(D)}$, Melisa TÜRKOĞLU LAÇIN (D) 1* \\ ${ }^{1}$ Yıldız Teknik Üniversitesi, Fen Edebiyat Fakültesi, İstanbul \\ Geliş Tarihi (Received): 23.05.2019, Kabul Tarihi (Accepted): 16.10.2019 \\ $\square$ Sorumlu Yazar (Corresponding author*): nelisalacin@gmail.com \\ (C) +902123834307 且 +902123834106
}

ÖZ

Kanser immünoterapisi, kanserle mücadelede insan immün sistemini güçlendirmeyi amaçlar ve immün sistemin kanser ile normal hücreler arasındaki en iyi biyokimyasal farklılıkları tespit etme yeteneğine dayanır. İmmünoterapi; özgüllüğü, uzun süreli etkileri ve iyileşmeye olan katkıları sayesinde, kanser tedavisindeki yerini sağlamlaştırmaya devam etmektedir. Tümörler, anti-tümör immün tepkilerini inhibe etmek için bağışıklık kontrol noktaları olarak da bilinen inhibitör reseptörleri kullanır. Birçok kişide immün-baskılamaya, Sitotoksik T-Lenfosit-liş̧kili Antijen-4 (CTLA-4) ve Programlanmış Ölüm-1 (PD-1) reseptörleri aracılık eder. CTLA-4 ve/veya PD-1 kontrol noktası inhibitörlerini hedefleyen monoklonal antikor $(\mathrm{mAb})$ temelli terapilerin, birçok farklı malignin türünde, hastalara gözle görülür yararlar sağladığı gözlemlenmiştir. Bu çalışmanın amacı, CTLA-4 ve PD-1/ PD-L1 tedavilerinin kanser tedavisindeki ve immünoterapideki yeri ile ilgili bilimsel çalışmaları incelemektir.

Anahtar Kelimeler: Kanser, immünoterapi, immün kontrol noktaları, CTLA-4, PD-1, PD-L1

\section{Immune Checkpoint Inhibitors: Ctla-4 and Pd-1/Pd-I1 in Immunotherapy}

\begin{abstract}
Cancer immunotherapy aims to strengthen the human immune system to combat cancer and is based on the ability of the immune system to detect the finest biochemical differences between cancer and normal cells. Immunotherapy's advantages among conventional methods are specificity to cancer cells, long-term effects and contribution to healing. Tumors use inhibitory receptors, also known as immune control points, to inhibit anti-tumor immune responses. In many individuals, immunosuppression is mediated by Cytotoxic T-Lymphocyte-Associated Antigen-4 (CTLA-4) and Programmed Death-1 (PD-1) receptors. Monoclonal antibody (mAb) based therapies targeting CTLA-4 and/or PD-1 control point inhibitors have been observed to provide significant benefits to patients of many different types of malignancies. This study aims to examine the scientific studies on the role of CTLA-4 and PD-1 / PD-L1 in cancer therapy and immunotherapy.
\end{abstract}

Keywords: Cancer, immunotherapy, immun checkpoints, CTLA-4, PD-1, PD-L1

\section{GíRiş}

İmmün sistem, çevremizde saldırmak için hazır bekleyen çok çeşitli sayıdaki organizma ve molekülleri tanıyan ve etkisiz hale getiren bir savunma mekanizmasıdır. Bağışıklığın temelini "kendinden olmayan" ile "kendinden olanın" ayırt edilebilmesi oluşturmaktadır. Bağışıklık sistemi, yabancı etkenlere karşı öldürmek, yok etmek ve izole etmek gibi birkaç savunma düzeneğine sahiptir ve olası aksiliklere karşı birbiriyle örtüşen yedek sistemler mevcuttur (Madigan, 2012; Campbell, 2013; Doan, 2017). 
Kanser-bağışıklık ilişkisi kavramı onlarca yıl öncesine dayanır ve bağışıklık sisteminin spontan tümörlerin gelişimini veya ilerlemesini baskılayabileceği hipotezini temel alır (Blomberg ve ark., 2018). Farklı teoriler öne sürülse de tümörlerin tek bir hücreden ortaya çıkması en çok kabul edilendir. Bu teoriye göre, birbirini takip eden mutasyonlar ve epigenetik değişimler birikir, çoğalmanın kontrolü kaybedilir ve koloniler şeklinde genişler, daha da fazla modifikasyon en gelişmiş tümör formuna dönüşümü sağlamak için birikir (Melo ve ark., 2018). Kanser, tümör baskılayıcı genler ve proto-onkogenlerde meydana gelen genetik ve epigenetik değişikliklerin birikmesi sonucu oluşan bir hastalıktır. Farklı kanser tiplerindeki birçok genetik çalışma, az sayıdaki bazı genlerin kötü huylu hücrelerin büyümesini desteklemek için mutasyona uğramış veya değiştirilmiş olması gerektiğini ortaya koymuştur (Baxter ve ark., 2014; Wang ve ark., 2018). Kanser hücreleri tipik olarak kanser olmayan hücrelere göre geniş bir genetik ve epigenetik değişim çeşitliliği taşırlar (Potapova ve Zhu, 2013).

Uzak organlara metastaz birçok kanser türünde hastaların en önemli ölüm nedenidir. Metastaz kanser ilişkili ölümlerin neredeyse \%90'ınını oluşturur. Buna rağmen dolaşımdaki tümör hücrelerinin $\% 0.01$ 'i sekonder lezyonlara ulaşmaya başarır (Joosse ve ark., 2015; Rejniak, 2016; Shenoy, 2016). Metastaz yapabilmek için, kanser hücreleri primer tümör kütlesinden ayrılmalıdır. Primer tümörü çevreleyen stromal dokular boyunca göç eder, kan ya da lenf dolaşım sistemine girer, kan akışıyla dolaşır ve sonunda yeni bir bölgeye geçiş yapıp lokal matriksi istila eder ve hedef organda kolonize olurlar (Masuda ve ark., 2016; Rejniak, 2016). Bu süreç temelde iki fazdan oluşur: fiziksel translokasyon ve kolonizasyon. Fiziksel translokasyon genelde epitelden mezankimal geçiş (EMG), intravazasyon (kanser hücrelerinin kan damarlarına geçişi) ve extravazasyonu (kanser hücrelerinin kan damarlarından ikincil organları istila için geçmesi) kapsar. Kolonizasyon; kanser hücrelerinin ikincil bölgelerdeki çoğalmasıdır (Shenoy, 2016).

Tüm bu değişken ortamlara uyum sağlayabilmek için hücrelerin belli bir özelliğe sahip olması gerekir, o da plastisitedir (Joosse ve ark., 2015); plastisite ise erişkin kök hücrelerin uygun ortam şartlarında ve uygun uyarılarla farklı doku ve hücrelere dönüşebilme yeteneğidir (Şahin Saydam ve Omay, 2005). Benzer şekilde, tümör hücreleri de hayatta kalabilmek için çeşitli stratejiler geliştirir. Hangi faktörlerin dolaşımdaki tümör hücrelerinin hayatta kalmalarını sağladığının daha iyi anlaşılması, yeni terapötik tedaviler tasarlamak için kullanılabilir (Hui ve Chen, 2015; Rejniak, 2016). Tümör hücrelerinin dolaşımdaki yolculuğu değerlendirildiğinde, tümör hücrelerinde meydana gelen değişikliklere ek olarak, mikroçevrenin bu süreçte kritik bir rol oynadığına dair artan kanıtlar bulunmaktadır (Joosse ve ark., 2015).
Son yıllardaki araştırmalar, tümörlerin korunmasının ve genişlemesinin aynı zamanda mikro ortamlarındaki dış sinyallere de güçlü bir şekilde bağlı olduğunu gösterdi. Tümör gelişimi ve ilerlemesini tam olarak anlamak için, kanser hücreleri ve bunların mikroçevreleri arasındaki etkileşimler hakkında daha derin bir bilgiye intiyaç bulunmaktadır (Wu ve Dai, 2017).

Tümör mikroçevresi (TMÇ), tümörün var olduğu hücresel ortamdır. TMÇ'de stromal hücreler, fibroblastlar, immün hücreler (örneğin $T$ lenfositleri, B lenfositleri, NK hücreler ve NK T hücreleri, Tümör ile ilişkili makrofajlar vb.) ve ayrıca perisitler bazen de adipositler dâhil olmak üzere farklı normal hücre tiplerini tanımlamıştır. Hepsi birlikte bu hücreler sıklıkla tümör stroması olarak adlandırılırlar ve ekstrasellüler matriks (ESM), oksijen seviyeleri ve $\mathrm{pH}$ ile birlikte, tümör mikroçevresini oluştururlar (Weber ve Kuo, 2012; Chiarugi ve Cirri, 2016; Wu ve Dai, 2017).

TMÇ'deki stromal hücreler ve fibroblastlar, hepatosit büyüme faktörü (HGF), fibroblast büyüme faktörü (FGF'ler) gibi büyüme faktörlerini salgılayabilir, bu da sadece malign hücrelerin büyümesini ve hayatta kalmasını teşvik eden değil diğer hücrelerin TMÇ'ye göçünü sağlayan bir kemoatraktan olarak da işlev görür (Hui ve Chen, 2015). EGF-epidermal büyüme faktörü, IGF-insülin benzeri büyüme faktörü ve FGF fibroblastlar tarafından salgılanan yerel çözünür büyüme faktörleridir (Weber ve Kuo, 2012). Kansere ilişkili fibroblastların (KIFs), TMÇ içerisindeki stromal hücrelerin büyük bir kısmını oluşturduğu gösterilmiştir. Kanser hücrelerinin çoğalmasını ve istilasını arttırarak, ESM'e kanser hücresi yapışmasını uyarır, matriks sertliğini artırır, dokular arası sıvının azalması nedeniyle dokular arası yüksek sıvı basıncı oluşur (Chiarugi ve Cirri, 2016; Wu ve Dai, 2017).

Dinamik tümör gelişimi süreci, tüm tümör mikro ortamının büyük bir şekilde yeniden yapılandırılmasına neden olur. Hipoksi, DNA bazlarında hasara neden olan reaktif oksijen türlerinin oluşmasına yol açar. Aynı zamanda, DNA'da tek ve çift zincirlerde kopmalara, anormal DNA sentezi için seçici baskı oluşmasına, mutasyonların büyümesine yol açar. Ek olarak, hipoksik koşulların, hasarlı DNA'nın onarımında bir azalmaya neden olduğu bulunmuştur (Weber ve Kuo, 2012). Hipoksi ile indüklenebilir faktör-1 (HIF-1) ile kontrol edilir. HIF-1 aktivasyonundan sonra, apoptoz, hücre döngüsü durdurma, anjiyogenez, glikoliz ve düşük pH'ye uyum gibi hücresel fonksiyonların düzenlenmesi söz konusu olur. Ekstrasellüler asitlik, TMÇ'nin temel bir özelliğidir. TMÇ içindeki $\mathrm{pH}$ 'ın düşürülmesi, lokal istila ve kanser hücresinin yayılmasını teşvik eder, MMP'leri aktive eder ve immün tepkinin bozulmasına katkıda bulunur (Weber 
ve Kuo, 2012; Chiarugi ve Cirri, 2016; Ivey ve ark., 2016; Hirata ve Sahai, 2017).

Tümör damarlarının yapısı ve fonksiyonu hemen hemen her bölgesinde anormaldir. Tümörün damar yapısı, büyümekte olan kitlenin taleplerini karşılamak için her zaman yetersizdir ve tümörün hipoksik ve asidik bölgelerinin oluşmasına yol açar. Normal bir kan damarı, TMÇ'deki hipoksik koşullardan anjiyojenik bir sinyal algıladığında, anjiyogenez uyarılır ve kaotik dallanma yapılarına sahip heterojen yeni damarlar, mevcut damar sisteminden filizlenir (Hui ve Chen, 2015).

Anjiyogenez, tümör büyümesinde ve metastazında önemli bir rol oynar. Trombosit kaynaklı büyüme faktörü (PDGF), FGF ve TGF- $\alpha$ gibi anjiyogenez sürecini düzenleyen bazı faktörler olmasına rağmen, VEGF genellikle kötü huylu tümör oluşumunda prototipik anjiyojenik molekül olarak kabul edilir (Wu ve Dai, 2017). HIF-1 ayrıca anjiyogenezde yer almaktadır (Weber ve Kuo, 2012). Dahası; ROS, VEGF ve anjiyopoietin salınımı ile perivasküler hücrelerin toplanmasını ve endotel progenitörlerinin aktivasyonunu indükleyerek de novo anjiyogenezini sürdürür (Catalano ve ark., 2013).

Çözünen faktörlerin salgılanmasıyla kanser hücreleri, sitokinler ve eksozomlar çevrelerini değiştirerek, tümör dokusunun gelişimi için zemin hazırlamasına neden olur. NF-kB transkripsiyon faktörü, inflamasyonda, glukoz açlığına metabolik adaptasyonun sağlanmasını kontrol edebilir (Chiarugi ve Cirri, 2016). TGF- $\beta$ ile ilgili, çoğalmayı baskılamak ile ilgili çalışmalarda, aşırı MMP üretilmesiyle mikroçevrenin bozulmasının, memeli hücrelerinin in vitro ve in vivo olarak genomik instabiliteye, epitelyal-mezenkimal geçişe yol açabileceğini ortaya koymuştur (Kenny ve ark., 2007; Weber ve Kuo, 2012). TNF- $\alpha$ başlangıçta baskın olarak anti-tümör aktivitesine sahip olduğuna inanılmasına rağmen, daha yakın zamanda birçok pro-tümörijenik fonksiyona sahip olduğu gösterilmiştir (Kenny ve ark., 2007).

ESM, tüm dokularda bulunan ve yaşam için gerekli olan üç boyutlu, hücresel olmayan bir yapıdır. Her organ, erken embriyonik aşamalarda üretilen, benzersiz kompozisyona sahip bir ESM'ye sahiptir. ESM'nin işlevi, doku bütünlüğü ve esnekliği için fiziksel desteğin ötesine geçmektedir. Doku homeostazını kontrol etmek için sürekli olarak yeniden düzenlenmiş dinamik bir yapıdır. ESM doku gelişimini ve homeostazı düzenler ve düzensizliği neoplastik gelişime katkıda bulunur. ESM, sadece dokuların düzenlendiği iskeleyi değil, hücre büyümesini, hayatta kalmayı, göç etmeyi ve farklılaşmayı yönlendiren ve damar gelişimi ve bağışıklık fonksiyonunu modüle eden kritik biyokimyasal ve biyomekanik ipuçlarını sağlar (Bonnans ve Chou, 2014; Pickup ve Mouw, 2014;
Multhaupt ve ark., 2016; Walker ve ark., 2018). Memelilerde ESM, çekirdek matrisomu olarak bilinen yaklaşık 300 proteinden oluşur ve kollajen, proteoglikanlar (PG'ler) ve glikoproteinler gibi proteinleri içerir. Kollajenler, ESM'in ana yapısal proteinleridir. Kollajen fibrilleri, dokuların yoğunluğunu sınırlandırarak ESM'ye gerilme gücü sağlar. Ek olarak, matrisomun bir parçası olmayan ancak yine de ESM'nin yeniden yapılandırılmasında önemli olan ESM ile ilişkili birçok protein vardır. Bu proteinler, büyüme faktörleri, sitokinler ve çapraz bağlanmada yer alan ESM değiştirici enzimlerdir (Bonnans ve Chou, 2014; Van Doren, 2015; Rainero, 2016).

MMP'ler, ESM degradasyonunda rol oynayan ana enzimlerdir. Aktiviteleri normal koşullarda düşüktür, ancak onarım işlemleri sırasında, hastalıklı veya inflamasyon olan dokularda artar (Bonnans ve Chou, 2014; Apte ve Parks, 2015; Deryugina ve Quigley, 2015; Shay ve ark., 2015). ESM'ye bağlı birçok sitokin ve büyüme faktörü örneği vardır. Örneğin, fibronektin alanlarının VEGF ve hepatik büyüme faktörü (HGF) dâhil olmak üzere birçok farklı büyüme faktörüne bağlandığı bulunmuştur. ESM proteinlerinin proteolitik bölünmesi, FGF'ler gibi büyüme faktörlerini serbest bırakır ve hücre çoğalmasına ve farklılaşmasına yön verir (Boyd, 2017).

ESM proteinleri çoğu kanserde aşırı eksprese edilir. Normal bir dokuya göre, büyük ölçüde çapraz bağlı ve yönlendirilmiş kollajen nedeniyle daha serttir. Bu sertleşmiş ESM, tümör saldırganlığı ile ilişkilidir. Laminin ekspresyonu, tümör invazivliği ile ilişkilidir. Ek olarak, daha sert bir ESM ile etkileşime giren hücreler, büyüme faktörlerine cevap olarak daha fazla çoğalır. Böylece, ESM ve reseptörleri, hücre proliferasyonunu düzenler ve bu etkileşimlerin bozulması, immün sistemin uyarılmasını ve tümör ilerlemesini modüle eder (Bourboulia ve StetlerStevenson, 2010; Pickup ve Mouw, 2014; Malik ve ark., 2015; Erdogan ve Webb, 2017).

Adaptif immün sistem tümör hücrelerinin normal olmadığını anlayabilme kapasitesine sahiptir ve CD8+ sitotoksik T lenfositler (STL'ler) onları öldürmek üzere tespit edebilir. Bu süreç tümör immün gözetimi olarak adlandırıır. İmmün gözetimi aşmanın tümörogenezin kritik bir aşaması olduğu kabul görmektedir ve T-hücre fonksiyonunu kısıtlayan kontrol noktalarını baskılayarak bu süreci tekrar aktive etmek potansiyel bir anti-kanser stratejisidir (Hirata ve Sahai, 2017). Çalışmalar, kronik inflamasyonlu dokuların genellikle yüksek kanser insidansı gösterdiğini göstermiştir. Ek olarak, yerleşik tümörler sıklıkla, üretken anti-tümör immünitesini bloke edebilen immün-baskılayıcı bir mikroçevrede bulunur (Hui ve Chen, 2015). Kronik inflamasyon, kanserin bir özelliğidir (Yang ve Lin, 2017). 
Tümör infiltre eden myeloid hücrelerin üç ana türü vardır: olgunlaşmamış myeloid hücreler, tümörle ilişkili makrofajlar (TiM) ve tümörle ilişkili nötrofiller (TIN) (Yang ve Lin, 2017). Makrofajlar polarizasyon durumlarına göre M1 ve M2 alt tiplerine ayrılabilir. M1 makrofajları Th1 interferon y (IFN-y) ve mikrobiyal ürünler ile aktive edilebilir. Buna karşılık M2 makrofajlar, IL-4, IL-10 ve IL-13 gibi Th-2 sitokinlerine cevap olarak farklılaşır. TiM'ler bağlamında, M1 makrofajlarının tümör öldürücü etki gösterdiği düşünülürken, M2 makrofajlarının tümörü desteklediği düşünülmektedir (Wu ve Dai, 2017). TíM'lerin işlevleri arasında; anjiyogeneze yol açan büyüme faktörlerinin üretimi, ESM'nin enzimlerle yeniden düzenlenmesi ve tümör hücrelerinin normal düzenleyici yollardan kaçmasına izin veren konak immün sisteminin baskılanması yer alır (Weber ve Kuo, 2012). Tümörlerde ve metastazlarda, nötrofiller makrofajlarınkine benzer proteazları ve proanjiyojenik faktörleri salgılarlar ve en baskın biçimde VEGF, FGF ve MMP salgılarlar. Nötrofillerin, ESM'den VEGF'yi serbest bırakmak için MMP-9 salgıladığı gösterilmiştir (Missiaen ve ark., 2018).

Tolerojenik dentritik hücreler, tümör antijen sunumunu bozarak, $T$ hücresi tükenmesini ve düzenleyici $T$ hücrelerini (Treg'ler) uyararak anti-tümör T- hücresi tepkilerini inhibe eder (Blomberg ve ark., 2018). CD4+ T hücreleri, TíM'ler gibi tümör teşvik edici immün hücrelerin aktivasyonunu ve polarizasyonunu destekleyen IL-4 ve IL-13 gibi sitokinler üretir. Kanser tipine bağlı olarak, Treg, tümör infiltrasyonlu lenfositlerin önemli bir bölümünü oluşturabilir. Her ne kadar immün-baskılayıcı aktiviteleri otoimmüniteyi ve patojenlere aşırı tepkileri önlemek için çok önemli olsa da, Treg'lerin özellikle tümör dokusunda birikmesi tümörlerin çoğunda daha kötü klinik sonuçlarla ilişkilidir (Yang ve Lin, 2017; Blomberg ve ark., 2018).

Tümör-destekleyici inflamasyon ve anjiyogenez birbirlerinden uzak ve ayrı süreçler olsa da, aslında birbirleriyle yakından ilişkili olaylar oldukları ve ortak kemokinlerle düzenlendiklerine dair hergün kanıtlar bulunmaktadır (Missiaen ve ark., 2018). B hücreleri, doğrudan VEGF, FGF2 ve MMP-9 gibi proanjiyojenik faktörler üreterek veya dolaylı olarak makrofajları immünbaskılayıcı ve proanjiyojenik bir fenotipe polarize ederek anjiyogenezi teşvik edebilir. Arginin-parçalayıcı enzim arginaz-1, anjiyogenik TiM'lerde daha fazla eksprese edilirken argininin ornitin ve üre halinde parçalanmasına neden olur (Blomberg ve ark., 2018; Missiaen ve ark., 2018).

Kanserli hastaların tedavisi için etkili immünoterapilerin olasılığı şimdi klinik bir gerçeklik haline gelmektedir. Bazı antikor tedavileri, bir hastanın kendi bağışıklık sistemini tümörlere karşı yönlendirme potansiyelini göstermiştir. Ek olarak, kanserlerin immün tanınmasında aktif olan sinyal kaskadlarının daha iyi anlaşılması, kanser immünoterapisi için önemli hedefler sağlaması açısından çok önemlidir (Church ve Galon, 2015; Hui ve Chen, 2015).

\section{İmmünoterapi nedir?}

Kanser immünoterapisi, kanser hücrelerini yok etmek için insan bağışıklık sistemini güçlendirmeyi amaçlar ( $\mathrm{Li}$ ve ark., 2016) ve immünoterapinin temelleri 19. yy'a kadar uzanır. Rudolf Virchow lökositlerin kötü huylu dokulara sızdığını ilk kez gözlemlemiştir. Bağışıklık sisteminin anti-tümör potansiyeli aynı yüzyılın sonlarına doğru William Coley tarafından ilk kez postulat olarak öne sürülmüştür. Coley toksini, tarihteki ilk kanser immünoterapi girişimidir (Marcucci ve ark., 2017; Aspeslagh ve ark., 2018; Zhang ve ark., 2018). Mevcut kanser immünoterapi stratejileri çoğunlukla T hücresi aracılı antitümör immünitesini onarmayı amaçlamaktadır (Gibney ve ark., 2016).

Kanser immünoterapisinin temel gerekçesi, bağışıklık sisteminin, kanser ve normal hücreler arasındaki en ince biyokimyasal farkları ayırt etmesini sağlayan, hem antikorların hem de $T$ hücrelerinin seçkin özgüllüklerini kullanmakta yatmaktadır (Rangel-Sosa ve ark., 2017). Onlarca yıl süren tartışmaların ardından, bağışıklık sisteminin insanlarda kanser hücrelerini hedefleme yeteneği, son birkaç yıl içerisinde immünoterapi ajanlarının anti-kanser terapötikleri olarak başarısı konusunda ikna edici bir şekilde gösterilmiştir (Rowshanravan ve ark., 2018).

Tümörler, anti-tümör immün tepkilerini inhibe etmek için çoklu immün düzenleyici mekanizmalar kullanır. Bunlara, "bağışıklık kontrol noktaları" olarak da bilinen inhibitör reseptörlerin aşırı ekspresyonu da dâhildir. İmmün kontrol noktalarını hedefleyen monoklonal antikorlar (mAb) kullanımı, efektör T hücrelerinin fonksiyonlarının bugüne kadarki en umut verici yaklaşımlardan biri olduğu gösterilmiştir (Walker ve Sansom, 2015; Rowshanravan ve ark., 2018). İmmün kontrol noktası blokajı (IKB), son yıllarda onkolojideki en cesaret verici gelişmelerden birini temsil etmekte ve etkileyici anti-tümör aktivitesi ve çeşitli ileri malignitelerdeki dayanıklı klinik fayda göstermiştir. Kavramsal olarak umut vaat eden bir diğer strateji, IKB immünoterapisini, kemoterapi ve radyoterapi gibi geleneksel kanser tedavileriyle birleştirmektir (Walker ve Sansom, 2015).

\section{İmmün kontrol noktası inhibitörlerì}

İmmün kontrol noktaları, immün yanıtları hassas şekilde ayarlamak için ortak uyarıcı yolakları fizyolojik olarak dengeleyen inhibitör yolaklardır. Başka bir deyişle, bir immün yanıtı durdurabilen normal immün sinyalleridir 
(Gibney ve ark., 2016). Bir immün kontrol noktasının iki bileşeni ile ilgili olarak, immün hücreler üzerinde eksprese edilen moleküller genellikle immün kontrol noktası reseptörleri olarak adlandırılırken, antijen sunan hücrelerde, tümör hücrelerinde veya diğer hücre tiplerinde immün kontrol noktası ligandları denir (Foy ve ark., 2016). İnhibitör veya uyarıcı immün kontrol noktası molekülleri, farklı tümör tiplerinde tümör hücrelerinin oldukça büyük bir kısmı üzerinde eksprese edilir. Son yıllarda, tümör hücrelerinde immün kontrol noktası moleküllerinin ekspresyonunun, tümör hücrelerinin biyolojisi üzerinde önemli sonuçları olduğu ortaya çıktı (Foy ve ark., 2016). Kanser gelişiminde kritik olan bu immün kontrol noktası inhibitörlerinin keşfi yeni tedavi stratejilerinin geliştirilmesi için yeni fırsatlar sunmuştur. Bu tedavi stratejileri, İnhibitör İmmün Konrol Noktası Blokajı (IKB) olarak adlandırılmaktadır (Walker ve Sansom, 2015; Lo ve Abdel-Motal, 2017; Nallasamy ve ark., 2018). İmmün kontrol noktası moleküllerinin tümör hücreleri tarafından aşırı ekspresyonu, kanser mikroçevresinde tümöre özgü T-hücresi bağışıklığını etkiler. Bu kontrol noktalarını kullanan tümör immün kaçış mekanizmalarının çoğu efektör hücre fonksiyonlarını bloke ettiğinden, anti-tümör immünitesi, inhibitör reseptör-ligand etkileşimini bloke eden ve böylece immün kontrol noktalarını inaktive eden antikorlar ile onarılabilir (Carosella ve ark., 2015).

İmmün sistem kanser gelişiminin kaderinin belirlenmesinde anahtar roller oynar. Birçok kişide immün-baskılamaya, $T$ hücrelerde eksprese edilen iki immünmodülatör reseptör olan Sitotoksik T lenfositle ilişkili molekül-4 (CTLA-4) ve Programlanmış Hücre Ölümü Ligand-1 (PD-1) aracılık eder. İnhibitör kontrol noktaları; toleransı ve immün homeostazını korumak ve immün aracılı doku hasarına karşı korumak için aktifleştirici sinyalleri ayarlar ve şekillendirir. Aynı zamanda da kanser sırasında gelişen ve böylece etkili anti-tümör bağışıkığını önleyen $T$ hücresi işlev bozukluğunun kilit aracılarıdır (Gubin ve ark., 2015). Hem CTLA-4 hem de PD-1, T hücrelerinin ko-inhibitör molekülleri olmasına rağmen, immün homeostaz üzerinde aynı etkiye sahip değildirler. CTLA-4 açısından eksik olan fareler, agresif lenfoproliferatif bozukluğun erken başlangıcı ile birlikte ölümcül bir fenotipe sahiptir. Buna karşılık, PD-1 eksikliği olan fareler hayatta kalır ve organ-spesifik otoimmün hastalıklara sahiptirler (Agrawal, 2019). Anti-PD-1 ve anti-CTLA-4 mAb'li immün kontrol noktası blokajı (IKB) son yıllarda onkolojideki en cesaret verici gelişmelerden birini temsil etmekte ve etkileyici antitümör aktivitesi ve çeşitli ileri malignitelerdeki dayanıklı klinik fayda göstermiştir. Bu cesaret verici sonuçlara dayanarak, çoklu PD1 veya PD-L1 inhibitörleri klinik gelişime girmiştir ve bazıları melanom gibi bazı endikasyonlar için $A B D$ Gıda ve İlaç İdaresi (FDA) ve Avrupa İlaç Ajansı (EMA) tarafIndan onaylanmıştır (Aspeslagh ve ark., 2018)

\section{Ctla-4}

Sitotoksik T-lenfositle ilişkili antijen 4 (CTLA-4), CD28: B7 immünoglobulin süper ailesinin bir üyesidir ve CTLA4, CD152 olarak da bilinir (Chowdhury ve ark., 2015). Normalde efektör $T$ hücrelerinin ve Treg hücrelerinin yüzeyinde düşük seviyelerde eksprese edilir. CTLA-4, öncelikle erken evre $T$ hücresi aktivasyonunun şiddetini düzenler (Gibney ve ark., 2016). Etki mekanizmalarından biri, CTLA-4'ün B7 için CD28'den daha yüksek bir afiniteye sahip olması nedeniyle ortaya çıkar. CTLA-4'ün CD80 / 86'ya bağlanması 500-2500 kez CD28'den daha etkindir. CD28 yoluyla sinyalleşme, sitokin IL-2'nin mRNA ekspresyonunu ve hücre döngüsüne girişini, T hücresi hayatta kalmasını, T yardımcı hücresi farklılaşmasını teşvik eder. Bu nedenle CTLA-4 sinyali, IL-2 mRNA üretimini inhibe ederek hücre döngüsü ilerlemesini inhibe eder. Bu mekanizma sadece CTLA-4'ün hücre dışı domainine bağlıdır. CTLA-4'ün T hücrelerini etkisiz hale getirebildiği ikinci bir mekanizma, negatif bir sinyal iletimini içerir. Bu mekanizma, CTLA-4'ün sitoplazmik kuyruğunu gerektirir ve düşük yüzey ifade seviyelerinde meydana gelir (Boussiotis, 2016; Gibney ve ark., 2016; Meng ve ark., 2018). CTLA-4, dendritik hücreler ve diğer ASH'ler tarafından ilk aktivasyon sırasında ağırlıklı olarak T hücrelerini düzenler. Ayrıca, CTLA-4 Treg ve bellek CD4+ hücreleri ile ifade edilir ve bu hücreler de CTLA-4 blokajı ile hedeflenebilir (Ott ve ark., 2013; Walker, 2013).

Adaptif bağışıklık tepkisinin başlaması iki sinyal gerektirir, ilki ana histouyumluluk kompleksi (MHC) ve T-hücre reseptörü (Sinyal 1) arasında antijen sunumu ve ikincisi B7 (CD80 veya CD86) ile CD28 kostimülasyonu arasında (Sinyal 2) gerçekleşir. Bir bağışıklık tepkisi başlatıldığında, tepkinin süresi ve genliği bir dizi farklı kontrol noktası tarafından modüle edilir. Bunlardan biri, B7 molekülleri için CD28'den daha güçlü bir afiniteye sahip olan CTLA-4'tür. CTLA-4, T hücresi aktivasyonundan yaklaşık 48 saat sonra yeniden düzenlenir ve naif ve hafıza $T$ hücrelerinin baskın-negatif sinyalleşme ile erken aktivasyonunu kontrol ederek primer fazda immün tepkinin zayıflamasına neden olur (Wing ve ark., 2011; Taube ve ark., 2018). CTLA-4, dendritik hücreler ve diğer ASH'ler tarafından ilk aktivasyon sırasında ağırlıklı olarak T hücrelerini düzenler. Ayrıca, CTLA-4 Treg ve bellek CD4+ hücreleri ile ifade edilir ve bu hücreler de CTLA-4 blokajı ile hedeflenebilir (Ott ve ark., 2013; Walker, 2013). CTLA-4'ün aktivasyonu, Treg hücrelerinin inhibitör fonksiyonunu güçlendirirken, interlökin-2 üretimi ve reseptörünün ifadesi azalır. Bu nedenle, CTLA-4 blokajı sitotoksik $T$ hücresi aktivasyonunu arttırır ve Treg hücresine bağlı immün baskılamayı inhibe eder, böylece anti-tümör aktivitesini gösterir (Şimşek ve ark., 2019). 
TMÇ'deki diğer bağışıklık düzenleyici mekanizmalarla birlikte sürekli antijene maruz kalmanın, yüksek seviyelerde ko-inhibitör reseptörleri (CTLA-4, PD-1, TIM-3, LAG-3, BTLA vb.) ifade edilmesine ve sitotoksisite ve efektör sitokinlerin üretimi (IFN-y, IL-2, TNF-a) gibi proliferasyon ve efektör fonksiyon kaybı ile tükenmiş-T hücrelerine yol açtığı gösterilmiştir. Bununla birlikte, T hücresi tükenmesi, geri döndürülemez değildir ve tükenmiş $T$ hücreleri tarafından ifade edilen ortak inhibitör yolaklar modüle edilerek, mevcut immün kontrol noktası inhibe edici tedavilerin temelini oluşturan $T$ hücrelerinin işlevsel olmayan hali tersine çevrilebilir (Agrawal, 2019). CTLA-4'e özgü bir insan monoklonal antikoru olan Ipilimumab (Yervoy), bu yeni kanser immünoterapisi sınıfından ilk FDA onaylı ilaçtır. Metastatik melanomalı hastalarda, ipilimumab tedavisi genel sağkalımı 3.6 ay arttırarak, hastaların \% 10-20'sinde kalıcı tümör regresyonu ile tam bir yanıt oluşturmuştur (Foy ve ark., 2016). Ipilimumab ve tremelimumab, CTLA-4'ü hedef alırlar (Ott ve ark., 2013). Tümör yanıtlarını kontrol noktası blokajına engelleyebilecek mekanizmaların çokluğu göz önüne alındığında, monoterapi olarak CTLA-4 blokajının uzun yıllar sürebilen kısmi ve tam tümör yanıtları oluşturması oldukça dikkat çekicidir (Ott ve ark., 2013). Ipilimumab'a cevabın dayanıklılığı, tedavinin başlamasından 3 yıl sonra \%20 hayatta kalma platosuna işaret eden 1861 hastanın faz II ve faz III klinik çalışmalarının uzun süreli analizleri ile gösterilmesi çok önemlidir (Van Hooren ve ark., 2017).

Anti-CTLA-4 ile tedavi edilen hastalar ile ilgili ana yan etkiler; dermatolojik, gastrointestinal, endokrin veya hepatik otoimmün reaksiyonlardır. Sistemik yan etkileri azaltırken terapötik etkinliği korumak için anti-CTLA-4 tedavisinin optimizasyonuna intiyaç vardır. Buna paralel olarak, klinik veriler PD-1 / PD-L1 yolunu bloke ederken, CTLA-4 yoluna kıyasla daha az toksisitesi olduğunu göstermektedir. Yine de, anti-CTLA-4 terapisi, ilk kullanıma hazır olduktan ve tedaviyi tümör dokusuna yerleştirdikten sonra yeni $T$ hücrelerini sürdürmek için son derece önemli olabilir ve ilk uygulamanın gerçekleştiği lenf nodülleri, sistemik toksisiteyi azaltmak için tercih edilen bir strateji olabilir (Van Hooren ve ark., 2017).

\section{Pd-1/ Pd-L1}

Farklılaşma kümesi 279 olarak da bilinen PD-1 (CD279), immünoglobulin gen süper ailesine ait bir hücre yüzeyi reseptörüdür. PD-1, insanlarda ve farelerde aktive edilmiş monositler, B hücreleri, T hücreleri, dendritik hücreler ve doğal öldürücü $T$ hücreleri üzerinde eksprese edilen ana immün kontrol noktası reseptörüdür. Hücre yapışması, çoğalması ve sitokin sinyalleşmesinde önemli bir rol oynar. Ayrıca $T$ hücresi fonksiyonunu baskılayarak kendi kendine toleransı sağlayabilir (Taube ve ark., 2018).

PD-1, CTLA-4'e kıyasla benzersiz özelliklere sahiptir. CTLA-4 hem hücre içi aktivitelere (efektör hücrelerde) hem de hücre dışı aktivitelere (Foxp3 + T hücrelerinde) sahiptir ve bu CTLA-4'ün eksikliğinin otoimmün fenotiplerini çok şiddetli ve antijene spesifik olmamasına neden olur. Buna karşılık, PD-1'in etkileri esas olarak intrinsiktir (Okazaki ve ark., 2013). Normal fizyolojik koşullar altında, PD-1'in iki ligandı bulunur: PD-L1 ve PD-L2; bu ligandlar, \% 37 dizi homolojisini paylaşır. Kanser hücreleri bağışıklık sistemi tarafından saldırıya uğradığında PD-L1 ve PD-L2 ekspresyonu artar, bu da T hücrelerinin baskılanmasına ve immün kaçışına yol açar (Nallasamy ve ark., 2018).

PD-L1, hücre dışı bölgelerden, transmembran bölgelerden ve hücre içi bölgelerden oluşan $40 \mathrm{kDa}$ ağırlığındaki bir tip I transmembran proteinidir. PD-L1; antijen sunan hücrelerde, lenfoid olmayan organlarda, ayrıca kalp, akciğer, plasenta ve karaciğer gibi hematopoietik olmayan hücrelerde temel olarak ifade edilir. Yaygın olarak ifade edilen PD-L1, periferal dokuları aşırı inflamasyon ve otoimmün patolojilerden korumak gibi kendine-tolerans ile ilgilidir (Li ve ark., 2016; Nallasamy ve ark., 2018). PD-L1, ürotelyal kanserler, gastrointestinal kanserler, akciğer kanseri, meme kanseri, melanom ve yumurtalık kanseri de dâhil olmak üzere çeşitli insan kanserlerinde eksprese edilir (Hamanishi ve ark., 2016).

PD-L1, başka bir T hücresi ile ilişkili immün kontrol noktası molekülü olan CD80 ile de etkileşime girebilir. PDL1'in PD-1 ile etkileşimi, immün yanıtların aşağı-regülasyonuna yol açar (Marcucci ve ark., 2017). Tümör hücresiyle ilişkili PD-L1'in ekspresyonuna yol açan iki genel mekanizma vardır: Birincisi tümör hücrelerine endojendir, ikincisi ise eksojendir ve tümör mikroçevresinden gelen uyaranlarla temsil edilir. IFN- $\gamma$, TNF- $\alpha$, VEGF, granülosit-makrofaj koloni-uyarıcı faktör (GM-CSF) ve IL-10 gibi çeşitli pro-inflamatuar sitokinler tarafından indüklenebilir. PD-L1 ayrıca Toll benzeri reseptörler (TLR'ler), interferon düzenleme faktörü 1 (IRF1), STAT1, STAT3 ve HIF-la ile indüklenebilir (Nallasamy ve ark., 2018).

PD-L1 aracılı adaptif bağışıklık direnci ilk önce melanomda tarif edilmiştir. Bu mekanizmada, gözetleyici $T$ hücreleri, tümör neoantijenlerini yabancı olarak tanır ve aktif hale gelirler, $\mathrm{PD}-1$ 'i düzenler ve IFN-ץ salgılarlar. IFN-ү'ye cevap olarak, tümör mikroçevresindeki tümör hücreleri ve immün hücreler PD-L1'i eksprese eder. PDL1 daha sonra PD-1'i bağlayarak gözetleyici T hücrelerini kapatabilirler (Taube ve ark., 2018). 
PD-1/PD-L1 yolunu hedefleyen immün kontrol noktası blokajı (IKB), melanom, renal hücreli karsinom, küçük hücreli akciğer kanseri ve mesane kanseri gibi çeşitli kanser türlerinde belirgin klinik cevaplara neden olur. PD-1 ve PD-L1 arasındaki etkileşimin antikorlarla bloke edilmesi, kanser hücrelerine karşı bağışıklık tepkisini arttırır (Zhang ve ark., 2018). PD-1/PD-L1 immün kontrol noktası yolunun antikorlar kullanılarak hedeflenmesi, kanser tedavisi denemelerinden çok önemli sonuçlar elde edilmiştir (Chowdhury ve ark., 2015). PD-1 veya PD-L1'in nivolumab ve pembrolizumab gibi bloke etmeye yönelik birçok mAb, kanser immünoterapisi için incelenmiştir ve farklı habis tümörlere sahip hastalarda etkileyici sonuçlar olduğu gösterilmiştir (Meng ve ark., 2018). PD-1/PD-L1 ko-inhibitör yolu terapötik olarak klinik denemelerde kullanıldığında çeşitli kanser türleri için \% 20 ila \% 50'lik bir cevap oranıyla dikkat çekici sonuçlar göstermiştir (Boussiotis, 2016).

2010 yılında, bir anti-PD-1 antikoru olan nivolumab'ın ilk faz I klinik denemesi, ileri melanom, küçük hücreli akciğer kanseri, renal hücreli karsinom, prostat kanseri ve kolorektal kanser gibi tedaviye dirençli katı tümörleri olan 39 hastada yapılmıştır. En sık görülen yan etkiler döküntü, ishal ve kaşıntı olarak rapor edilmiştir (Hamanishi ve ark., 2016). Faz III klinik deneyleri, PD-1/PD-L1 eksenini bozan ajanların, tam tepkiler sağlama ve önceden tedavi edilemeyen kanserlerde hayatta kalma süresini uzatma kabiliyeti dâhil olmak üzere önemli bir etkinliğe sahip olduğunu göstermiştir. PD-1 bloke edici ajanlar, hematolojik malignitelerden katı tümörlere kadar geniş bir yelpazedeki histolojilerde aktivite göstermiştir (Majzner ve ark., 2017).

\section{SONUÇLAR}

Kanser sürekli kendini yenileyen ve birçok farklı mekanizmayı bir arada kullanan bir hastalıktır. Hastalık ilerledikçe artan mutasyonlar ve kanser hücrelerinin metastaz yaparak çoğalması tedaviyi zorlaştıır. Özellikle ilerleyen evrelerde tümörleri etkin bir şekilde hedeflemek bu karmaşık mekanizmalar ve mutasyonlar nedeniyle zordur. Kemoterapi ve radyoterapi kanser tedavisinin temelini oluştursa da etkin hedeflemede yetersiz olduklarından ve birçok yan etkilerinden dolayı başka tedavi arayışları devam etmiştir.

Kanserin mikroçevresinde immün hücreleriyle bir arada bulunduğu bilinmekteydi. Aynı zamanda kanser ve immün sistem arasında sıkı bir iletişim olduğu, salgılanan sitokinler ve kemokinlerle görülmektedir. İmmün sistem temelde kendine yabancı olanı tanıma prensibiyle çalışır ve tümör hücreleri de anormal bir durumu temsil ettiğinden immün sistemin hücreleri tarafından tanınırlar. Ancak kanser ilerledikçe tümör mikroçevresi de buna göre şekillenir ve immün sistem hücreleri mikroçevreden aldıkları sinyaller nedeniyle işlevsiz hale gelirler. Bu süreçte bazı immün kontrol noktası inhibitörlerinin etkili olduğu bulunmuştur. Özellikle T hücreleri üzerinde bulunan bu kontrol noktaları, tümör gelişimi için kritiktir.

İmmünoterapi, bu immün kontrol noktası inhibitörlerini bloke ederek tekrar $\mathrm{T}$ hücrelerinin fonksiyonlarının geri kazanılmasını ve tümör hücreleriyle savaşmayı amaçlamaktadır. Özellikle öne çıkan kontrol noktaları CTLA-4 ve PD-1/PD-L1'dir ve bunlara karşı monoklonal antikorlar geliştirilmiştir. CTLA-4 için geliştirilen Ipilimumab ve PD-1 için Nivolumab ve Pembrolizumab monoklonal antikorları FDA tarafından onaylarak hastalarda kullanılmaya başlamıştır. Tedavideki başarıları, immünoterapi araştırmalarının ve başka stratejilerin geliştirilmesinin önünü açmıştır.

\section{KAYNAKLAR}

Agrawal, B. (2019). New therapeutic targets for cancer: the interplay between immune and metabolic checkpoints and gut microbiota. Clin Transl Med. 8: 23.

Apte, S. S., Parks, W. C. (2015). Metalloproteinases: A parade of functions in matrix biology and an outlook for the future. Matrix Biology, 44-46, 1-6.

Aspeslagh, S., Solinas, C., Routy, B. (2018). Immuno-oncology-101: overview of major concepts and translational perspectives. Seminars in Cancer Biology, 52(February), $1-11$.

Baxter, E., Windloch, K., Gannon, F., Lee, J. S. (2014). Epigenetic regulation in cancer progression. Cell and Bioscience, 4(1).

Blomberg, O. S., Spagnuolo, L., de Visser, K. E. (2018). Immune regulation of metastasis: mechanistic insights and therapeutic opportunities. Disease Models \& Mechanisms, 11(10), dmm036236.

Bourboulia, D., Stetler-Stevenson, W. G. (2010). Matrix metalloproteinases (MMPs) and tissue inhibitors of metalloproteinases (TIMPs): Positive and negative regulators in tumor cell adhesion. Seminars in Cancer Biology, 20(3), 161168.

Boussiotis, V. A. (2016). Molecular and Biochemical Aspects of the PD-1 Checkpoint Pathway. The New England Journal of Medicine, 375(18), 1767-1778.

Campbell, R. (2013). Biyoloji (9th ed.). Istanbul: Palme Yayıncllık.

Bonnans, C., Chou, J., (2014). Remodelling the extracellular matrix in development and disease. Nat Rev Mol Cell Biol., 15(12), 786-801.

Carosella, E. D., Ploussard, G., LeMaoult, J. ve Desgrandchamps, F. (2015). A Systematic Review of Immunotherapy in Urologic Cancer: Evolving Roles for Targeting of CTLA4, PD-1/PD-L1, and HLA-G, European Urology, vol. 68, no. 2. Elsevier, 267-279.

Catalano, V., Turdo, A., Di Franco, S., Dieli, F., Todaro, M., Stassi, G. (2013). Tumor and its microenvironment: A synergistic interplay. Seminars in Cancer Biology, 23(6), 522-532.

Chiarugi, P., Cirri, P. (2016). Metabolic exchanges within tumor microenvironment. Cancer Letters, 380(1), 272-280. 
Chowdhury, F., Dunn, S., Mitchell, S., Mellows, T., AshtonKey, M., Gray, J. C. (2015). PD-L1 and CD8 + PD1 + lymphocytes exist as targets in the pediatric tumor microenvironment for immunomodulatory therapy. Oncolmmunology, 4(10), e1029701.

Church, S. E., Galon, J. (2015). Tumor Microenvironment and Immunotherapy: The Whole Picture Is Better Than a Glimpse. Immunity, 43(4), 631-633.

David F. Boyd, (2017). Towards Integrating Extracellular Matrix and Immunological Pathways, 98, 79-86.

Deryugina, E. I., Quigley, J. P. (2015). Tumor angiogenesis: MMP-mediated induction of intravasation- and metastasissustaining neovasculature. Matrix Biology, 44-46, 94-112.

Doan, M. V. W. (2017). İmmünoloji (2nd ed.). Istanbul: Nobel Tıp Kitabevleri.

Erdogan, B., Webb, D. J. (2017). Cancer-associated fibroblasts modulate growth factor signaling and extracellular matrix remodeling to regulate tumor metastasis. Biochem Soc Trans., 45(1), 229-236.

Foy, S. P., Mandl, S. J., dela Cruz, T., Cote, J. J., Gordon, E. J., Trent, E., Rountree, R. B. (2016). Poxvirus-based active immunotherapy synergizes with CTLA-4 blockade to increase survival in a murine tumor model by improving the magnitude and quality of cytotoxic T cells. Cancer Immunology, Immunotherapy, 65(5), 537-549.

Gibney, G. T., Weiner, P. L. M., Atkins, P. M. B., Comprehensive, L. (2016). Predictive biomarkers for checkpoint inhibitor-based immunotherapy. Lancet Oncol., 17(12), 542551.

Gubin, M. M. ve ark., (2015). Checkpoint Blockade Cancer Immunotherapy Targets Tumour- Specific Mutant Antigens, Nature, vol. 515, no. 7528, 577-581.

Hamanishi, J., Mandai, M., Matsumura, N., Abiko, K., Baba, T., Konishi, I. (2016). PD-1/PD-L1 blockade in cancer treatment: perspectives and issues. International Journal of Clinical Oncology, 21(3), 462-473.

Hirata, E., Sahai, E. (2017). Tumor Microenvironment and Differential. Cold Spring Harb Perspect

Hui, L., Chen, Y. (2015). Tumor microenvironment: Sanctuary of the devil. Cancer Letters, 368(1), 7-13.

Ivey, J. W., Bonakdar, M., Kanitkar, A., Davalos, R. V., Verbridge, S. S. (2016). Improving cancer therapies by targeting the physical and chemical hallmarks of the tumor microenvironment. Cancer Letters, 380(1), 330-339.

Joosse, S. A., Gorges, T. M., Pantel, K. (2015). Biology, detection, and clinical implications of circulating tumor cells. EMBO Molecular Medicine, 7(1), 1-11.

Kenny, P. A., Lee, G. Y., Bissell, M. J. (2007). Targeting the tumor microenvironment. Frontiers in Bioscience, 12, 3468-3474.

Li, Y., Li, F., Jiang, F., Lv, X., Zhang, R., Lu, A., Zhang, G. (2016). A mini-review for cancer immunotherapy: Molecular understanding of PD-1/ PD-L1 pathway \& translational blockade of immune checkpoints. International Journal of Molecular Sciences, 17(7), 1-22.

Lo, B., Abdel-Motal, U. M. (2017, December 1). Lessons from CTLA-4 deficiency and checkpoint inhibition. Current Opinion in Immunology. Elsevier Ltd.

Madigan, J. M. M. (2012). Mikroorganizmaların Biyolojisi (11th ed.). Istanbul: Palme Yayıncılık.

Majzner, R. G., Simon, J. S., Grosso, J. F., Martinez, D., Pawel, B. R., Santi, M., Maris, J. M. (2017). Assessment of programmed death-ligand 1 expression and tumor-associated immune cells in pediatric cancer tissues. Cancer, 123(19), 3807-3815.

Malik, R., Lelkes, P. I., Cukierman, E. (2015). BIOMECHANICAL and BIOCHEMICAL REMODELING of STROMAL EXTRACELLULAR MATRIX IN CANCER. Trends Biotechnol., 33(4), 230-236.

Marcucci, F., Rumio, C., Corti, A. (2017). Tumor cell-associated immune checkpoint molecules - Drivers of malignancy and stemness. Biochimica et Biophysica Acta - Reviews on Cancer, 1868(2), 571-583.

Masuda, T., Hayashi, N., Iguchi, T., Ito, S., Eguchi, H., Mimori, K. (2016). Clinical and biological significance of circulating tumor cells in cancer. Molecular Oncology, 10(3), 408-417.

Melo, F. H. M. de, Oliveira, J. S., Sartorelli, V. O. B., Montor, W. R. (2018). Cancer Chemoprevention: Classic and Epigenetic Mechanisms Inhibiting Tumorigenesis. What Have We Learned So Far? Frontiers in Oncology, 8(December), $1-15$.

Meng, Y., Liang, H., Hu, J., Liu, S., Hao, X., Wong, M. S. K., Hu, L. (2018). PD-L1 Expression Correlates With Tumor Infiltrating Lymphocytes And Response To Neoadjuvant Chemotherapy In Cervical Cancer. Journal of Cancer, 9(16), 2938-2945.

Pickup, M., Mouw, K., (2014). The extracellular matrix modulates the hallmarks of cancer. EMBO Reports, 15, 12431253.

Missiaen, R., Mazzone, M., Bergers, G. (2018). The reciprocal function and regulation of tumor vessels and immune cells offers new therapeutic opportunities in cancer. Seminars in Cancer Biology, 52(June), 107-116.

Multhaupt, H. A. B., Leitinger, B., Gullberg, D., Couchman, J. R. (2016). Extracellular matrix component signaling in cancer. Advanced Drug Delivery Reviews, 97, 28-40.

Nallasamy, P., Chava, S., Verma, S. S., Mishra, S., Gorantla, S., Coulter, D. W., Challagundla, K. B. (2018). PD-L1, inflammation, non-coding RNAs, and neuroblastoma: Immuno-oncology perspective. Seminars in Cancer Biology, 52(July 2017), 53-65.

Okazaki, T., Chikuma, S., Iwai, Y., Fagarasan, S., Honjo, T. (2013). A rheostat for immune responses: The unique properties of PD-1 and their advantages for clinical application. Nature Immunology, 14(12), 1212-1218.

Ott, P. A., Hodi, F. S., Robert, C. (2013). CTLA-4 and PD-1/PDL1 blockade: New immunotherapeutic modalities with durable clinical benefit in melanoma patients. Clinical Cancer Research, 19(19), 5300-5309.

Parkin, D. M., Bray, F., Ferlay, J., Pisani, P. (2005). Global Cancer Statistics, 2002. CA: A Cancer Journal for Clinicians, 55(2), 74-108.

Potapova T., Zhu J., (2013). Aneuploidy and chromosomal instability: a vicious cycle driving cellular evolution and cancer genome chaos. Cancer Metastasis Rev., 32(0).

Rainero, E. (2016). Extracellular matrix endocytosis in controlling matrix turnover and beyond: emerging roles in cancer. Biochemical Society Transactions, 44(5), 1347-1354.

Rangel-Sosa, M. M., Aguilar-Córdova, E., Rojas-Martínez, A. (2017, September 30). Immunotherapy and gene therapy as novel treatments for cancer. Colombia Medica (Cali, Colombia).

Rejniak, K. A. (2016). Circulating Tumor Cells: When a Solid Tumor Meets a Fluid Microenvironment. Advances in Experimental Medicine and Biology, 936, 93-106. 
Rowshanravan, B., Halliday, N., Sansom, D. M. (2018, January 4). CTLA-4: A moving target in immunotherapy. Blood. American Society of Hematology.

Shay, G., Lynch, C. C., Fingleton, B. (2015). Moving targets: Emerging roles for MMPs in cancer progression and metastasis. Matrix Biology, 44-46, 200-206.

Shenoy, J. L. (2016). Cancer cells remodel themselves and vasculature to overcome the endothelial barrier. Cancer Lett., 380(2), 534-544.

Şahin, F., Saydam, G., Omay, S. (2005). Kök Hücre Plastisitesi ve Klinik Pratikte Kök Hücre Tedavisi. Türk Homotoji-Onkoloji Derneği, Vol.15, 48-56.

Şimşek, M., Tekin, S. B., Bilici, M. (2019). Immunological Agents Used in Cancer Treatment. Eurasian J Med. 51(1): 90-94.

Taube, J. M., Galon, J., Sholl, L. M., Rodig, S. J., Cottrell, T. R., Giraldo, N. A., David, L. (2018). Implications of the tumor immune microenvironment for staging and therapeutics. Mod Pathol., 31(2), 214-234.

Van Doren, S. R. (2015). Matrix metalloproteinase interactions with collagen and elastin. Matrix Biology, 44-46(i), 224231.

Van Hooren, L., Sandin, L. C., Moskalev, I., Ellmark, P., Dimberg, A., Black, P., Mangsbo, S. M. (2017). Local checkpoint inhibition of CTLA-4 as a monotherapy or in combination with anti-PD1 prevents the growth of murine bladder cancer. European Journal of Immunology, 47(2), 385-393.
Walker, C., Mojares, E., del Río Hernández, A. (2018). Role of Extracellular Matrix in Development and Cancer Progression. International Journal of Molecular Sciences (Vol. 19).

Walker, L. S. K. (2013, September). Treg and CTLA-4: Two intertwining pathways to immune tolerance. Journal of Autoimmunity.

Walker, L. S. K., Sansom, D. M. (2015, February 1). Confusing signals: Recent progress in CTLA-4 biology. Trends in Immunology. Elsevier Ltd.

Wang, L. H., Wu, C. F., Rajasekaran, N., Shin, Y. K. (2018). Loss of Tumor Suppressor Gene Function in Human Cancer: An Overview. Cellular Physiology and Biochemistry, 2647-2693.

Weber, C. E., Kuo, P. C. (2012). The tumor microenvironment. Surgical Oncology, 21(3), 172-177.

Wing, K., Yamaguchi, T., Sakaguchi, S., (2011). Cell-autonomous and -non-autonomous roles of CTLA-4 in immune regulation, Trends in Immunology, vol. 32, no. 9. 428-433.

Wu, T., Dai, Y. (2017). Tumor microenvironment and therapeutic response. Cancer Letters, 387, 61-68. https://doi.org/10.1016/j.canlet.2016.01.043

Yang, L., Lin, P. C. (2017). Mechanisms that drive inflammatory tumor microenvironment, tumor heterogeneity, and metastatic progression. Seminars in Cancer Biology, 47(July), 185-195.

Zhang, X., Wang, C., Wang, J., Hu, Q., Langworthy, B., Ye, Y., Gu, Z. (2018). PD-1 Blockade Cellular Vesicles for Cancer Immunotherapy. Advanced Materials (Deerfield Beach, Fla.), 30(22), e1707112. 